\title{
BreastCare
}

\section{PD-1 and PD-L1 Immune Checkpoint Blockade to Treat Breast Cancer}

\author{
Andreas D. Hartkopf ${ }^{a} \quad$ Florin-Andrei Taran ${ }^{a}$ Markus Wallwiener ${ }^{b}$ Christina B. Walter $^{a}$ \\ Bernhard Krämer $^{a}$ Eva-Maria Grischke ${ }^{a}$ Sara Y. Brucker ${ }^{a}$ \\ a Department of Women's Health, University of Tübingen, Tübingen, Germany; \\ ${ }^{b}$ Department of Obstetrics and Gynecology, University of Heidelberg, Heidelberg, Germany
}

\section{Keywords \\ Breast cancer · Immunotherapy · PD-1 - PD-L1 . \\ Clinical trials}

\section{Summary}

Immune checkpoint inhibition represents a major recent breakthrough in the treatment of malignant diseases including breast cancer. Blocking the programmed death receptor-1 (PD-1) and its ligand, PD-L1, has shown impressive antitumor activity and may lead to durable long-term disease control, especially in the triple-negative subtypes of breast cancer (TNBC). Although immune checkpoint blockade is generally well tolerated, specific immune-related adverse events (irAEs) may occur. This review summarizes the clinical efficacy, perspectives, and future challenges of using PD-1/PD-L1-directed antibodies in the treatment of breast cancer.

(C) 2016 S. Karger GmbH, Freiburg

\section{Introduction}

The immune system plays an integral role in cancer development and therefore potentially offers novel targeted therapies. Complex interactions of tumor cells, immune effector cells, stromal cells, and soluble factors are crucial for disease progression and/or eradication of tumor cells [1]. Hence, the modulation of immunogenic regulators (checkpoints) is a promising approach to treat malignant disease [2]. The programmed death receptor-1 (PD-1) and its ligand, PD-L1, are increasingly recognized as powerful targets to enhance tumor-directed cytotoxic T-cell function.
The PD-1-blocking antibodies pembrolizumab and nivolumab obtained Food and Drug Administration (FDA) approval for the treatment of advanced melanoma in 2014, and of non-small-cell lung cancer (NSCLC) in 2015 [3-7].

As breast cancer is also capable of stimulating immune responses, targeting the immune system is an encouraging strategy for its treatment. Triple-negative breast cancer (TNBC) in particular seems highly immunogenic because tumor-infiltrating lymphocytes (TILs), which have been demonstrated to positively correlate with response to cytotoxic therapy and prognosis, are predominantly present within hormone receptor (HR)-negative subtypes [8-11]. Encouraging results from phase I trials using checkpoint inhibitors directed against PD-1/PD-L1 have been reported, and phase II and III trials are currently ongoing. In this review, we aim to summarize recent data on PD-1/PD-L1 antibodies to treat breast cancer. While our focus lies on clinical experience and challenges, we also cover the underlying preclinical rationale of these highly promising agents.

\section{Biology and Preclinical Rationale of Targeting PD-1 and PD-L1}

Although the immune system protects its host against malignant tumor cells, it can also promote cancer development by selecting for tumor cell clones that escape immune surveillance [12, 13]. Interaction between cancer progression and immune response occurs in 3 phases. In the initial elimination phase, an acute inflammatory response activates immune effector cells (macrophages, dendritic cells, natural killer cells) that migrate into the tumor microenvironment. However, some tumor cell clones may still survive (immunosurveillance), shifting inflammation to a chronic equilibrium phase that may last for a period of many years. Finally, the tumor escapes from immune detection (escape phase), result-

\section{KARGER}

() 2016 S. Karger GmbH, Freiburg

Fax +497614520714 
Fig. 1. Simplified illustration of the complex interaction between PD-1 and PD-L1. To initiate an antitumor immune response, tumor-specific antigens $(\mathrm{Ag})$ are presented to $\mathrm{T}$ cells via the major histocompatibility complex (MHC). Interaction of the programmed death receptor-1 (PD-1) with its ligands (PD-L1/PD-L2) induces a negative control signal on T-cell activity that enables tumor cells to escape immune defense. Blocking the PD-1/PD-L1 axis with specific antibodies $(\mathrm{Ab})$ promotes antitu-

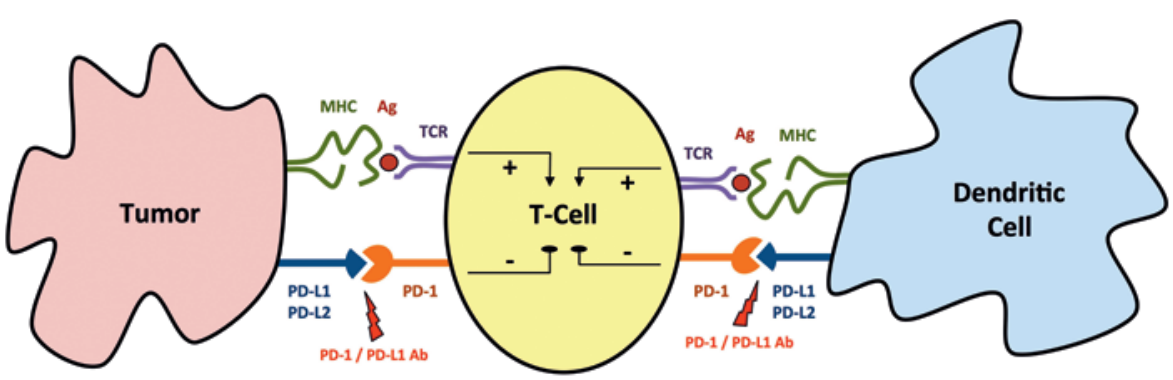
mor immune activity. TCR $=\mathrm{T}$-cell receptor.

ing in autonomous outgrow and metastatic spread. Modulation of immune-regulating checkpoints aims at impeding immune escape and enhancing tumor-directed immune responses.

PD-1 is an immune checkpoint receptor that is expressed by activated lymphocytes ( $\mathrm{T}$ and B cells, natural killer cells, monocytes, dendritic cells, myeloid cells, thymocytes). Interaction with its ligands PD-L1 or PD-L2 induces a negative control signal that limits T cell activity. PD-L1 suppresses autoimmunity and is constitutively expressed by $\mathrm{T}$ and $\mathrm{B}$ cells, dendritic cells, macrophages, mesenchymal stem cells, and mast cells [14]. It is also upregulated in multiple solid malignancies including breast cancer [15-18]. Figure 1 illustrates a condensed snapshot of the complex interaction between PD1 and PD-1/PD-L1 that occurs at multiple steps of an antitumor immune response and enables tumor cells to evade the immune defense [19].

Preclinical in vivo models have shown that blocking the PD-1/ PD-L1 axis promotes T cell-mediated antitumor immune activity and that PD-1-deficient mice develop various spontaneous autoimmune diseases [20-22]. A number of antibodies directed against PD-1 (nivolumab, pembrolizumab, pidilizumab, PDR001) or its ligand PD-L1 (atezolizumab, durvalumab, avelumab, BMS936559) are currently under clinical investigation. Table 1 summarizes ongoing clinical trials, identified at ClinicalTrials.gov.

There are several reasons why most current trial protocols focus on TNBC:

- PD-L1 expression is highest in TNBC (approximately 20-30\% of all TNBCs express PD-L1) [15, 23].

- A significant infiltration of TILs that facilitate immune response has been reported in TNBC [8-11, 24-26].

- Loss of PTEN correlates with HR-negative breast cancer and leads to upregulation of PD-L1 [27, 28].

- TNBC is associated with a higher mutational burden that can produce immunogenic neoantigens [27, 29].

- Apart from chemotherapy, treatment alternatives for TNBC are limited, which is in contrast to HR-positive or human epidermal growth factor receptor 2 (HER2)-positive breast cancer.

\section{Clinical Experiences in Targeting PD-1 and PD-L1 for Breast Cancer Treatment}

The humanized monoclonal antibody pembrolizumab is highly selective for PD-1. KEYNOTE is a series of clinical trials to deter- mine whether pembrolizumab is effective in the treatment of various cancers. In the phase I trial KEYNOTE-12, Nanda et al. [30] recently found clinical activity and an acceptable safety profile of pembrolizumab given intravenously at $10 \mathrm{mg} / \mathrm{kg}$ every 2 weeks to women with PD-L1-positive TNBC. The expression rate for PD-L1 was $59 \%$ and 32 patients were enrolled. Only 5 patients (16\%) had toxicities grade $\geq 3$. Although most patients were heavily pretreated, the overall response rate was $19 \%$, with durations of response of up to 47 weeks (median duration not yet reached). Currently, there are ongoing phase II (KEYNOTE-86, NCT02447003) and phase III clinical trials (KEYNOTE-119, NCT02555657) that will evaluate pembrolizumab as a monotreatment for TNBC while other phase I-III studies investigate the combination of pembrolizumab with chemotherapy (table 1).

Atezolizumab (MPDL3280A) is a humanized monoclonal antibody that binds to PD-L1. Emens et al. [31] presented results of a phase I trial in patients with metastatic TNBC. Atezolizumab administered at $15 \mathrm{mg} / \mathrm{kg}, 20 \mathrm{mg} / \mathrm{kg}$, or a $1200-\mathrm{mg}$ flat dose every 2 weeks was well tolerated, and only $11 \%$ of a heavily pretreated population experienced adverse events of grade $\geq 3$ (adrenal insufficiency, neutropenia, nausea, vomiting, and 1 pulmonary hypertension event in a patient with an atrial septal defect). Among $21 \mathrm{pa}-$ tients whose data were ready for efficacy evaluation at the time of data presentation, 3 patients had partial remission and 2 patients had complete remission. Additionally, 3 patients appeared to have progressive disease but later showed evidence of durable nonclassical responses ('pseudoprogression'). Overall, the 24 -week progression-free survival rate was $33 \%$.

Adams et al. [32] investigated the combination of nanoparticle albumin-bound paclitaxel (nab-paclitaxel; $125 \mathrm{mg} / \mathrm{m}^{2}$, days 1,8 , $15, \mathrm{q} 4 \mathrm{w})$ with atezolizumab ( $800 \mathrm{mg}, \mathrm{q} 2 \mathrm{w})$ in 32 patients with metastatic TNBC. The most common treatment-related toxicity was neutropenia (53\% all grades; $41 \%$ grade $3-4$ ). No dose-limiting toxicity or drug-related deaths occurred. Among the 24 patients who were evaluable at the time of data analysis, 1 had complete remission and 16 had partial response. In addition, 3 patients developed new lesions and were therefore scored as having progressive disease, but remained on treatment with prolonged biologic response. Treatment efficacy was observed in both PD-L1-positive and PD-L1-negative patients. An ongoing phase III trial (IMpassion) is currently evaluating the combination of atezolizumab and nab-paclitaxel in previously untreated patients with metastatic TNBC (NCT02425891). 
Table 1. Ongoing clinical trials with antibodies directed against PD-1/PD-L1 to treat breast cancer

\begin{tabular}{|c|c|c|c|c|c|}
\hline Antibody & Target & $\begin{array}{l}\text { Study identifier } \\
\text { (study name) }\end{array}$ & Phase & Breast cancer subtype & Combination with \\
\hline $\begin{array}{c}\text { Pembrolizumab } \\
\text { (MK3475) }\end{array}$ & $\begin{array}{l}\text { PD-1 } \\
\text { PD-L1 }\end{array}$ & $\begin{array}{l}\text { NCT02555657 } \\
\text { (KEYNOTE-119) } \\
\text { NCT02555657 } \\
\text { (KEYNOTE-355) }\end{array}$ & III & $\begin{array}{l}\text { advanced TN } \\
\text { advanced TN }\end{array}$ & mono-CTX \\
\hline $\begin{array}{l}\text { Atezolizumab } \\
\quad \text { (MPDL3280A) }\end{array}$ & & $\begin{array}{l}\text { NCT02425891 } \\
\text { (IMpassion) }\end{array}$ & & advanced TN & nab-paclitaxel \\
\hline $\begin{array}{l}\text { Pembrolizumab } \\
\text { (MK3475) }\end{array}$ & PD-1 & $\begin{array}{l}\text { NCT02648477 } \\
\text { NCT02447003 } \\
\text { (KEYNOTE-086) } \\
\text { NCT02752685 } \\
\text { NCT02644369 } \\
\text { (INSPIRE) }\end{array}$ & II & $\begin{array}{l}\text { advanced HER2+ } \\
\text { advanced TN } \\
\text { advanced HER2- } \\
\text { advanced TN }\end{array}$ & $\begin{array}{l}\text { doxorubicin/aromatase } \\
\text { inhibitor }\end{array}$ \\
\hline $\begin{array}{l}\text { Atezolizumab } \\
\quad \text { (MPDL3280A) }\end{array}$ & PD-L1 & $\begin{array}{l}\text { NCT02530489 } \\
\text { (TN first line) }\end{array}$ & & neoadjuvant TN & nab-paclitaxel \\
\hline $\begin{array}{l}\text { Durvalumab } \\
\qquad \text { (MEDI4736) }\end{array}$ & PD-L1 & $\begin{array}{l}\text { NCT02669914 } \\
\text { NCT02536794 } \\
\text { NCT02685059 } \\
\text { (GeparNuevo) }\end{array}$ & & $\begin{array}{l}\text { brain metastases } \\
\text { advanced HER2- } \\
\text { neoadjuvant TN }\end{array}$ & $\begin{array}{l}\text { tremelilumab } \\
\text { neoadjuvant CTX }\end{array}$ \\
\hline PDR001 & PD-1 & $\begin{array}{l}\text { NCT02404441 } \\
\text { NCT02404441 }\end{array}$ & I-II & $\begin{array}{l}\text { advanced TN } \\
\text { advanced TN }\end{array}$ & \\
\hline $\begin{array}{l}\text { Pembrolizumab } \\
\quad(\text { MK3475) }\end{array}$ & PD-1 & $\begin{array}{l}\text { NCT02129556 } \\
\text { (PANACEA) } \\
\text { NCT02657889 } \\
\text { (KEYNOTE-162) }\end{array}$ & & $\begin{array}{l}\text { advanced HER2+ } \\
\text { advanced TN }\end{array}$ & $\begin{array}{l}\text { trastuzumab } \\
\text { mono-CTX }\end{array}$ \\
\hline & & $\begin{array}{l}\text { NCT02513472 } \\
\text { NCT02452424 }\end{array}$ & & $\begin{array}{l}\text { advanced TN } \\
\text { advanced TN }\end{array}$ & $\begin{array}{l}\text { eribulin } \\
\text { PLX3397 }\end{array}$ \\
\hline $\begin{array}{l}\text { Atezolizumab } \\
\quad(\text { MPDL3280A) }\end{array}$ & PD-L1 & $\begin{array}{l}\text { NCT02543645 } \\
\text { NCT02708680 }\end{array}$ & & $\begin{array}{l}\text { advanced TN } \\
\text { advanced TN }\end{array}$ & $\begin{array}{l}\text { varlilumab } \\
\text { entinostat }\end{array}$ \\
\hline $\begin{array}{l}\text { Avelumab } \\
\qquad \text { (MSB0010718C) }\end{array}$ & PD-L1 & NCT02554812 & & advanced TN & $\begin{array}{l}\text { PF-05082566, } \\
\text { PF-04518600 }\end{array}$ \\
\hline $\begin{array}{l}\text { Durvalumab } \\
\text { (MEDI4736) }\end{array}$ & PD-L1 & $\begin{array}{l}\text { NCT02484404 } \\
\text { NCT02734004 } \\
\text { NCT02489448 }\end{array}$ & & $\begin{array}{l}\text { advanced TN } \\
\text { advanced } \\
\text { gBRCA+/HER2- } \\
\text { neoadjuvant TN }\end{array}$ & $\begin{array}{l}\text { olaparib/cediranib } \\
\text { olaparib } \\
\text { neoadjuvant CTX }\end{array}$ \\
\hline $\begin{array}{l}\text { Nivolumab } \\
\quad \text { (BMS-936558) }\end{array}$ & PD-1 & NCT02309177 & I & advanced HER- & nab-paclitaxel \\
\hline $\begin{array}{l}\text { Pembrolizumab } \\
\quad(\text { MK3475) }\end{array}$ & PD-1 & $\begin{array}{l}\text { NCT02622074 } \\
\text { (KEYNOTE-172) } \\
\text { NCT01975831 } \\
\text { NCT02622074 } \\
\text { (KEYNOTE-173) }\end{array}$ & & $\begin{array}{l}\text { neoadjuvant TN } \\
\text { advanced non-TN } \\
\text { neoadjuvant TN }\end{array}$ & $\begin{array}{l}\text { neoadjuvant CTX } \\
\text { tremelilumab } \\
\text { neoadjuvant CTX }\end{array}$ \\
\hline & & NCT02452424 & & advanced TN & enoblituzumab \\
\hline $\begin{array}{l}\text { Atezolizumab } \\
\text { (MPDL3280A) }\end{array}$ & PD-L1 & $\begin{array}{l}\text { NCT01375842 } \\
\text { NCT02605915 }\end{array}$ & & $\begin{array}{l}\text { advanced } \\
\text { advanced HER2+ }\end{array}$ & $\begin{array}{l}\text { trastuzumab }+ \\
\text { pertuzumab/T-DM1 }\end{array}$ \\
\hline $\begin{array}{l}\text { Avelumab } \\
\quad \text { (MSB0010718C) }\end{array}$ & PD-L1 & NCT01772004 & & advanced & \\
\hline $\begin{array}{l}\text { Durvalumab } \\
\quad \text { (MEDI4736) }\end{array}$ & PD-L1 & $\begin{array}{l}\text { NCT02628132 } \\
\text { NCT02649686 }\end{array}$ & & $\begin{array}{l}\text { advanced TN } \\
\text { advanced HER2+ }\end{array}$ & $\begin{array}{l}\text { paclitaxel } \\
\text { trastuzumab }\end{array}$ \\
\hline
\end{tabular}

Avelumab (MSB0010718C) is a human anti-PD-L1 antibody. In a phase 1 trial, presented by Dirix et al. [33], 168 patients with metastatic or advanced breast cancer of any subtype received $10 \mathrm{mg} / \mathrm{kg}$ avelumab every 2 weeks. Adverse events of any grade occurred in
$71 \%$ of the patients, with fatigue $(20 \%)$, nausea $(14 \%)$, and infusion-related reactions (12\%) being the most common. $14 \%$ of the patients experienced toxicities of grade $\geq 3$ (fatigue, anemia, increased $\gamma$-glutamyl transferase (GGT)/autoimmune hepatitis, and 
arthralgia) and there were 2 treatment-related deaths (acute liver failure, respiratory distress). 9 patients responded to treatment ( 1 complete response and 8 partial responses). 5 of these 9 responses were ongoing at the time of data analysis. Responders were among all subtypes of breast cancer. There was a numerical higher response rate in $\mathrm{PD}-\mathrm{L} 1$-expressing TNBC patients.

\section{Managing Toxicity and Side-Effects of PD-1- and PD-L1-Directed Treatment}

The spectrum of immune-related adverse events (irAEs) differs from the toxicity known from other anticancer drugs. Although the huge majority of events are mild (grade 1-2) and reversible, clinicians should be aware of the toxicity profile of PD-1 checkpoint inhibitors to avoid delay in diagnosis and treatment [34]. irAEs can affect any organ system, but typically include the skin, the gastrointestinal (GI) tract, and the hepatic, endocrine and respiratory systems [35]. Other rare events such as uveitis, pancreatitis, hematological events, neurologic adverse events, and nephritis have also been reported [36-40]. In general, irAEs are manageable by the use of immunosuppressive therapy (e.g. glucocorticoids) without impeding the antitumor response. Whether checkpoint blockade can trigger an underlying autoimmune disorder is unclear as these patients have been excluded from clinical trials.

The most common toxicities are skin-related events. Reticular, maculopapular, erythematous rash and/or pruritus is frequent and typically involves the trunk and extremities [35, 41]. Rash and other low-grade dermatologic events can be treated with topical glucocorticoids and oral antipruritics (mainly antihistamines). Oral mucositis and dry mouth are also common and can be treated using oral corticosteroid rinses and lidocaine [7, 35]. Other dermatologic events include urticaria, vitiligo, and palmoplantar erythrodysesthesia [34]. Grade 3-4 events are rare; however, StevensJohnson syndrome and toxic epidermal necrolysis requiring hospitalization, discontinuation of checkpoint blockade, and intravenous corticosteroid treatment have been reported [35].

Diarrhea or colitis begins approximately after 6 weeks of checkpoint blockade and occurs in $10-20 \%$ of the patients, with a relatively low rate of grade 3-4 events (1-2\%) [34]. Early symptoms can present as watery or bloody diarrhea, abdominal pain, fever, weight loss, and nausea or vomiting. Clostridium difficile and other infectious etiologies should be excluded and colonoscopy may be helpful to confirm or rule out colitis. Intravenous corticosteroids, hydration, and electrolyte management are required in severe cases. In patients who are refractory to corticosteroids, treatment with infliximab can be considered [42, 43].

Increased liver function test values are seen in approximately $5 \%$ of the patients; they are generally asymptomatic and mainly of grade $1-2[5,44]$. As the onset of elevated liver enzyme levels is highly variable, hepatic function should be monitored before each treatment cycle. Management includes an oral corticosteroid or oral mycophenolate mofetil if the liver function test values do not decrease [35].
Endocrinopathies that can affect the pituitary, adrenal, and thyroid glands often present with non-specific symptoms such as headache, fatigue, weight gain or loss, and nausea. Although hypophysitis has rarely been reported in patients treated with PD-1/ PD-L1-blocking agents and thyroiditis occurs in less than $10 \%$ of the patients, severe cases have been described [7, 44, 45]. Diagnosis is made by characteristic laboratory findings. In addition, radiographic changes such as an enlargement of the pituitary gland may occur $[46,47]$. Thus, monitoring of the thyroid stimulation hormone (TSH) during checkpoint blockade is recommended [34]. Treatment consists of corticosteroids and, if necessary, hormonal supplementation. The very rare case of an adrenal crisis must be considered if dehydration, hypotension, and electrolyte imbalances occur [34].

For the respiratory system, the leading symptoms of non-infectious pneumonitis are dry and unproductive cough, dyspnea, and tachypnea. Diagnostic procedures include imaging (computed tomography (CT) scans), lung function tests, and a bronchoscopy in moderate to severe cases to exclude infectious etiologies (especially viral or atypical bacterial germs). Treatment consists of corticosteroids and, in severe or refractory cases, immunosuppressive agents such as mycophenolate mofetil, infliximab, or cyclophosphamide [34].

\section{Future Challenges of PD-1- and PD-L1-Directed Treatment}

The patterns of response to immune checkpoint blockade may differ from classical response criteria, such as the Response Evaluation Criteria in Solid Tumors (RECIST) [2]. The time to achieve clinical response to treatment may be prolonged and can manifest after an initial increase in tumor burden or the onset of new tumor lesions [48]. In contrast to chemotherapy, where stable disease is often regarded as transient, achievement of stable disease by the use of immunotherapeutic agents may be viewed as an indicator of a meaningful therapeutic effect [49]. Therefore, Wolchok et al. [49] and Nishino et al. [50] proposed guidelines for the evaluation of immune therapy activity in solid tumors. These immune-related response criteria continue to be refined, and further prospective evaluation is warranted.

In the era of precision oncology, predictive factors that forecast the efficacy of immune checkpoint therapy are essential to identify patients who are most likely to benefit from PD-1/PD-L1-directed therapy. Additionally, biomarkers that monitor tumor-specific immune responses as well as irAEs are warranted. A recent metaanalysis of patients with malignant melanoma or NSCLC demonstrated a significant association of PD-L1 expression and response to PD-1/PD-L1-directed treatment [51]. Nevertheless, PD-L1-negative patients may still respond to $\mathrm{PD}-1$ blockade. Therefore, assessment of PD-L1 expression to identify patients for PD-1/PD-L1directed therapy should be considered with caution and is not yet ready for clinical routine [2]. Biological and technical challenges have to be considered and standardization is required as different 
antibodies and cut-off values have been used for immunohistochemistry (IHC) staining in recent trials [14]. Furthermore, PD-L1 expression is a dynamic marker which can change in response to disease progression and treatment $[52,53]$. Examples of other biomarkers that are currently under investigation are mutational load, neoantigens, the presence of TILs, inflammatory gene signatures, and blood-based immune biomarkers [16, 54-57].

Combination approaches, such as adding other immunotherapeutic, cytotoxic, or targeted agents to PD-1/PD-L1 antibodies may enhance checkpoint inhibition. However, it is still unclear if any specific combination is superior to single-agent treatment [2]. The optimal dose and schedule of immune checkpoint blockade need to be determined in future clinical trials.

\section{Conclusions}

Early clinical trials of using antibodies directed against PD-1 and PD-L1 to treat breast cancer patients demonstrated exciting clinical activity. However, given the complexity of breast cancer biology and immune responses to breast cancer, many questions remain to be answered. Examples are optimal dosing, scheduling, combination approaches, response criteria, and biomarkers for immunotherapy. Clinical experience with respect to the management of irAEs is warranted. As immunotherapies may establish durable long-term disease control, this approach holds great promise to significantly improve the outcome of breast cancer patients.

\section{Disclosure Statement}

All authors declare that they have no conflicts of interest.

\section{References}

1 Cimino-Mathews A, Foote JB, Emens LA: Immune targeting in breast cancer. Oncology (Williston Park) 2015;29:375-385.

2 Postow MA, Callahan MK, Wolchok JD: Immune checkpoint blockade in cancer therapy. J Clin Oncol 2015;33:1974-1982.

3 Robert C, Schachter J, Long GV, Arance A, Grob JJ, Mortier L, Daud A, Carlino MS, McNeil C, Lotem M, Larkin J, Lorigan P, Neyns B, Blank CU, Hamid O, Mateus C, Shapira-Frommer R, Kosh M, Zhou H, Ibrahim N, Ebbinghaus S, Ribas A, KEYNOTE-006 investigators: Pembrolizumab versus ipilimumab in advanced melanoma. N Engl J Med 2015;372:2521-2532.

4 Garon EB, Rizvi NA, Hui R, Leighl N, Balmanoukian AS, Eder JP, Patnaik A, Aggarwal C, Gubens M, Horn L, Carcereny E, Ahn MJ, Felip E, Lee JS, Hellmann MD, Hamid O, Goldman JW, Soria JC, Dolled-Filhart M, Rutledge RZ, Zhang J, Lunceford JK, Rangwala R, Lubiniecki GM, Roach C, Emancipator K, Gandhi L; KEYNOTE-001 investigators: Pembrolizumab for the treatment of non-small-cell lung cancer. N Engl J Med 2015;372:2018-2028.

5 Topalian SL, Hodi FS, Brahmer JR, Gettinger SN, Smith DC, McDermott DF, Powderly JD, Carvajal RD, Sosman JA, Atkins MB, Leming PD, Spigel DR, Antonia SJ, Horn L, Drake CG, Pardoll DM, Chen L, Sharfman WH, Anders RA, Taube JM, McMiller TL, Xu H, Korman AJ, Jure-Kunkel M, Agrawal S, McDonald D, Kollia GD, Gupta A, Wigginton JM, Sznol M: Safety, activity, and immune correlates of anti-PD-1 antibody in cancer. N Engl J Med 2012;366:2443-2454.

6 Brahmer JR, Tykodi SS, Chow LQ, Hwu WJ, Topalian SL, Hwu P, Drake CG, Camacho LH, Kauh J, Odunsi K, Pitot HC, Hamid O, Bhatia S, Martins R, Eaton K, Chen S, Salay TM, Alaparthy S, Grosso JF, Korman AJ, Parker SM, Agrawal S, Goldberg SM, Pardoll DM, Gupta A, Wigginton JM: Safety and activity of antiPD-L1 antibody in patients with advanced cancer. N Engl J Med 2012;366:2455-2465.

$\checkmark 7$ Topalian SL, Sznol M, McDermott DF, Kluger HM, Carvajal RD, Sharfman WH, Brahmer JR, Lawrence DP, Atkins MB, Powderly JD, Leming PD, Lipson EJ, Puzanov I, Smith DC, Taube JM, Wigginton JM, Kollia GD, Gupta A, Pardoll DM, Sosman JA, Hodi FS: Survival, durable tumor remission, and long-term safety in patients with advanced melanoma receiving nivolumab. J Clin Oncol 2014;32:1020-1030.
8 Denkert C, von Minckwitz G, Brase JC, Sinn BV, Gade S, Kronenwett R, Pfitzner BM, Salat C, Loi S, Schmitt WD, Schem C, Fisch K, Darb-Esfahani S, Mehta K, Sotiriou C, Wienert S, Klare P, André F, Klauschen F, Blohmer JU, Krappmann K, Schmidt M, Tesch H, Kümmel S, Sinn P, Jackisch C, Dietel M, Reimer T, Untch M, Loibl S: Tumor-infiltrating lymphocytes and response to neoadjuvant chemotherapy with or without carboplatin in human epidermal growth factor receptor 2-positive and triple-negative primary breast cancers. J Clin Oncol 2015;33:983-991.

9 Loi S, Sirtaine N, Piette F, Salgado R, Viale G, Van Eenoo F, Rouas G, Francis P, Crown JP, Hitre E, de Azambuja E, Quinaux E, Di Leo A, Michiels S, Piccart MJ, Sotiriou C: Prognostic and predictive value of tumor-infiltrating lymphocytes in a phase III randomized adjuvant breast cancer trial in node-positive breast cancer comparing the addition of docetaxel to doxorubicin with doxorubicin-based chemotherapy: BIG 02-98. J Clin Oncol 2013;31:860-867.

10 Loi S, Michiels S, Salgado R, Sirtaine N, Jose V, Fumagalli D, Kellokumpu-Lehtinen PL, Bono P, Kataja V, Desmedt C, Piccart MJ, Loibl S, Denkert C, Smyth MJ, Joensuu H, Sotiriou C: Tumor infiltrating lymphocytes are prognostic in triple negative breast cancer and predictive for trastuzumab benefit in early breast cancer: results from the FinHER trial. Ann Oncol 2014;25: 1544-1550.

11 Adams S, Gray RJ, Demaria S, Goldstein L, Perez EA, Shulman LN, Martino S, Wang M, Jones VE, Saphner TJ, Wolff AC, Wood WC, Davidson NE, Sledge GW, Sparano JA, Badve SS: Prognostic value of tumor-infiltrating lymphocytes in triple-negative breast cancers from two phase III randomized adjuvant breast cancer trials: ECOG 2197 and ECOG 1199. J Clin Oncol 2014; 32:2959-2966.

12 Dunn GP, Old LJ, Schreiber RD: The three Es of cancer immunoediting. Annu Rev Immunol 2004;22:329360.

13 Kim R, Emi M, Tanabe K: Cancer immunoediting from immune surveillance to immune escape. Immunology 2007;121:1-14

14 Ma W, Gilligan BM, Yuan J, Li T: Current status and perspectives in translational biomarker research for PD-1/PD-L1 immune checkpoint blockade therapy. J Hematol Oncol 2016;9:47.
5 Mittendorf EA, Philips AV, Meric-Bernstam F, Qiao N, Wu Y, Harrington S, Su X, Wang Y, Gonzalez-Angulo AM, Akcakanat A, Chawla A, Curran M, Hwu P, Sharma P, Litton JK, Molldrem JJ, Alatrash G: PD-L1 expression in triple-negative breast cancer. Cancer Immunol Res 2014;2:361-370.

16 Schalper KA, Velcheti V, Carvajal D, Wimberly H, Brown J, Pusztai L, Rimm DL: In situ tumor PD-L1 mRNA expression is associated with increased TILs and better outcome in breast carcinomas. Clin Cancer Res 2014;20:2773-2782.

17 Wimberly H, Brown JR, Schalper K, Haack H, Silver MR, Nixon C, Bossuyt V, Pusztai L, Lannin DR, Rimm DL: PD-L1 expression correlates with tumor-infiltrating lymphocytes and response to neoadjuvant chemotherapy in breast cancer. Cancer Immunol Res 2015;3:326-332.

18 Ali HR, Glont SE, Blows FM, Provenzano E, Dawson SJ, Liu B, Hiller L, Dunn J, Poole CJ, Bowden S, Earl HM, Pharoah PD, Caldas C: PD-L1 protein expression in breast cancer is rare, enriched in basal-like tumours and associated with infiltrating lymphocytes. Ann Oncol 2015;26:1488-1493.

19 Pardoll DM: The blockade of immune checkpoints in cancer immunotherapy. Nat Rev Cancer 2012;12:252264.

20 Nishimura H, Okazaki T, Tanaka Y, Nakatani K, Hara M, Matsumori A, Sasayama S, Mizoguchi A, Hiai H, Minato N, Honjo T: Autoimmune dilated cardiomyopathy in PD-1 receptor-deficient mice. Science 2001; 291:319-322.

21 Nishimura H, Nose M, Hiai H, Minato N, Honjo T: Development of lupus-like autoimmune diseases by disruption of the PD-1 gene encoding an ITIM motifcarrying immunoreceptor. Immunity 1999;11:141-151.

22 Hirano F, Kaneko K, Tamura H, Dong H, Wang S, Ichikawa M, Rietz C, Flies DB, Lau JS, Zhu G, Tamada $\mathrm{K}$, Chen L: Blockade of B7-H1 and PD-1 by monoclonal antibodies potentiates cancer therapeutic immunity. Cancer Res 2005;65:1089-1096.

23 Ghebeh H, Mohammed S, Al-Omair A, Qattan A, Lehe C, Al-Qudaihi G, Elkum N, Alshabanah M, Bin Amer S, Tulbah A, Ajarim D, Al-Tweigeri T, Dermime S: The B7-H1 (PD-L1) T lymphocyte-inhibitory molecule is expressed in breast cancer patients with infiltrating ductal carcinoma: correlation with important high-risk prognostic factors. Neoplasia 2006;8:190-198. 
24 Bates GJ, Fox SB, Han C, Leek RD, Garcia JF, Harris AL, Banham AH: Quantification of regulatory T cells enables the identification of high-risk breast cancer patients and those at risk of late relapse. J Clin Oncol 2006;24:5373-5380.

25 Liu S, Lachapelle J, Leung S, Gao D, Foulkes WD, Nielsen TO: CD8+ lymphocyte infiltration is an independent favorable prognostic indicator in basal-like breast cancer. Breast Cancer Res 2012;14:R48.

26 Liyanage UK, Moore TT, Joo HG, Tanaka Y, Herrmann V, Doherty G, Drebin JA, Strasberg SM, Eberlein TJ, Goedegebuure PS, Linehan DC: Prevalence of regulatory $\mathrm{T}$ cells is increased in peripheral blood and tumor microenvironment of patients with pancreas or breast adenocarcinoma. J Immunol 2002;169:27562761.

27 Cancer Genome Atlas Network: Comprehensive molecular portraits of human breast tumours. Nature 2012;490:61-70.

28 Saal LH, Holm K, Maurer M, Memeo L, Su T, Wang X, Yu JS, Malmstrom PO, Mansukhani M, Enoksson J, Hibshoosh H, Borg A, Parsons R: PIK3CA mutations correlate with hormone receptors, node metastasis, and ERBB2, and are mutually exclusive with PTEN loss in human breast carcinoma. Cancer Res 2005;65: 2554-2559.

-29 Shah SP, Roth A, Goya R, Oloumi A, Ha G, Zhao Y, Turashvili G, Ding J, Tse K, Haffari G, Bashashati A, Prentice LM, Khattra J, Burleigh A, Yap D, Bernard V, McPherson A, Shumansky K, Crisan A, Giuliany R, Heravi-Moussavi A, Rosner J, Lai D, Birol I, Varhol R, Tam A, Dhalla N, Zeng T, Ma K, Chan SK, Griffith M, Moradian A, Cheng SW, Morin GB, Watson P, Gelmon K, Chia S, Chin SF, Curtis C, Rueda OM, Pharoah PD, Damaraju S, Mackey J, Hoon K, Harkins T, Tadigotla V, Sigaroudinia M, Gascard P, Tlsty T, Costello JF, Meyer IM, Eaves CJ, Wasserman WW, Jones S, Huntsman D, Hirst M, Caldas C, Marra MA, Aparicio S: The clonal and mutational evolution spectrum of primary triple-negative breast cancers. Nature 2012;486:395-399.

30 Nanda R, Chow LQ, Dees EC, Berger R, Gupta S, Geva R, Pusztai L, Pathiraja K, Aktan G, Cheng JD, Karantza V, Buisseret L: Pembrolizumab in patients with advanced triple-negative breast cancer: phase Ib KEYNOTE-012 study. J Clin Oncol 2016;34:2460-2467.

31 Emens LA, Braiteh FS, Cassier P, Delord J-P, Eder JP, Fasso M, Xiao Y, Wang Y, Molinero L, Chen DS, Krop I: Inhibition of PD-L1 by MPDL3280A leads to clinical activity in patients with metastatic triple-negative breast cancer. Annual Meeting of the American Association for Cancer Research 2015; abstr 2859.

32 Adams S, Robinson Diamond J, Hamilton EP, Raffin Pohlmann P, Tolaney SM, Molinero L, He X, Waterkamp D, Funke RP, Powderly JD: Phase Ib trial of atezolizumab in combination with nab-paclitaxel in patients with metastatic triple-negative breast cancer. J Clin Oncol 2016;34(suppl):abstr 1009.

33 Dirix LY, Takacs I, Nikolinakos P, Jerusalem G, Arkenau H-T, Hamilton EP, von Heydebreck A, Grote H-J, Chin K, Lippman ME: Avelumab (MSB0010718C), an anti-PD-L1 antibody, in patients with locally advanced or metastatic breast cancer: a phase Ib JAVELIN solid tumor trial. San Antonio Breast Cancer Symposium 2015; abstr S1-04.
34 Eigentler TK, Hassel JC, Berking C, Aberle J, Bachmann O, Grünwald V, Kähler KC, Loquai C, Reinmuth N, Steins M: Diagnosis, monitoring and management of immune-related adverse drug reactions of anti-PD-1 antibody therapy. Cancer Treat Rev 2016; 45:7-18.

35 Postow MA: Managing Immune Checkpoint-Blocking Antibody Side Effects. Alexandria, VA, American Society of Clinical Oncology Educational Book, 2015.

36 Robinson MR, Chan C-C, Yang JC, Rubin BI, Gracia GJ, Sen HN, Csaky KG, Rosenberg SA: Cytotoxic T lymphocyte-associated antigen 4 blockade in patients with metastatic melanoma: a new cause of uveitis. J Immunother 2004;27:478-479.

37 Di Giacomo AM, Danielli R, Guidoboni M, Calabrò L, Carlucci D, Miracco C, Volterrani L, Mazzei MA, Biagioli $\mathrm{M}$, Altomonte M: Therapeutic efficacy of ipilimumab, an anti-CTLA-4 monoclonal antibody, in patients with metastatic melanoma unresponsive to prior systemic treatments: clinical and immunological evidence from three patient cases. Cancer Immunol Immunother 2009;58:1297-1306.

38 Akhtari M, Waller EK, Jaye DL, Lawson DH, Ibrahim R, Papadopoulos NE, Arellano ML: Neutropenia in a patient treated with ipilimumab (anti-CTLA-4 antibody). J Immunother 2009;32:322-324.

39 Wilgenhof S, Neyns B: Anti-CTLA-4 antibody-in duced Guillain-Barre syndrome in a melanoma patient. Ann Oncol 2011;22:991-993.

40 Izzedine $\mathrm{H}$, Gueutin V, Gharbi C, Mateus C, Robert C, Routier E, Thomas M, Baumelou A, Rouvier P: Kidney injuries related to ipilimumab. Invest New Drugs 2014; 32:769-773.

41 Belum V, Benhuri B, Postow M, Hellmann M, Lesokhin A, Segal N, Motzer R, Wu S, Busam K, Wolchok J: Characterisation and management of dermatologic adverse events to agents targeting the PD-1 receptor. Eur J Cancer 2016;60:12-25.

42 Pagès C, Gornet JM, Monsel G, Allez M, Bertheau P, Bagot M, Lebbé C, Viguier M: Ipilimumab-induced acute severe colitis treated by infliximab. Melanoma Res 2013;23:227-230.

43 Merrill SP, Reynolds P, Kalra A, Biehl J, Vandivier RW, Mueller SW: Early administration of infliximab for severe ipilimumab-related diarrhea in a critically ill patient. Ann Pharmacother 2014;48:806-810.

44 Hamid O, Robert C, Daud A, Hodi FS, Hwu W-J, Kefford R, Wolchok JD, Hersey P, Joseph RW, Weber JS: Safety and tumor responses with lambrolizumab (antiPD-1) in melanoma. N Engl J Med 2013;369:134-144.

45 Robert C, Long GV, Brady B, Dutriaux C, Maio M, Mortier L, Hassel JC, Rutkowski P, McNeil C, KalinkaWarzocha E: Nivolumab in previously untreated melanoma without BRAF mutation. N Engl J Med 2015; 372:320-330.

46 Blansfield JA, Beck KE, Tran K, Yang JC, Hughes MS, Kammula US, Royal RE, Topalian SL, Haworth LR, Levy C: Cytotoxic T-lymphocyte-associated antigen-4 blockage can induce autoimmune hypophysitis in patients with metastatic melanoma and renal cancer. J Immunother 2005;28:593-598.

47 Dillard T, Yedinak CG, Alumkal J, Fleseriu M: AntiCTLA-4 antibody therapy associated autoimmune hypophysitis: serious immune related adverse events across a spectrum of cancer subtypes. Pituitary 2010; 13:29-38.
48 Wolchok J, Weber J, Maio M, Neyns B, Harmankaya K, Chin K, Cykowski L, de Pril V, Humphrey R, Lebbé C: Four-year survival rates for patients with metastatic melanoma who received ipilimumab in phase II clinical trials. Ann Oncol 2013;24:2174-2180.

49 Wolchok JD, Hoos A, O’Day S, Weber JS, Hamid O Lebbe C, Maio M, Binder M, Bohnsack O, Nichol G, Humphrey R, Hodi FS: Guidelines for the evaluation of immune therapy activity in solid tumors: immunerelated response criteria. Clin Cancer Res 2009; 15 : 7412-7420.

50 Nishino M, Giobbie-Hurder A, Gargano M, Suda M, Ramaiya NH, Hodi FS: Developing a common language for tumor response to immunotherapy: immune-related response criteria using unidimensional measurements. Clin Cancer Res 2013;19:3936-3943.

51 Gandini S, Massi D, Mandalà M: PD-L1 expression in cancer patients receiving anti PD-1/PD-L1 antibodies: a systematic review and meta-analysis. Crit Rev Oncol Hematol 2016;100:88-98.

52 McLaughlin J, Han G, Schalper KA, Carvajal-Hausdorf D, Pelekanou V, Rehman J, Velcheti V, Herbst R LoRusso P, Rimm DL: Quantitative assessment of the heterogeneity of PD-L1 expression in non-small-cell lung cancer. JAMA Oncol 2016;2:46-54.

53 Herbst RS, Baas P, Kim DW, Felip E, Perez-Gracia JL, Han JY, Molina J, Kim JH, Arvis CD, Ahn MJ, Majem M, Fidler MJ, de Castro G Jr, Garrido M, Lubiniecki GM, Shentu Y, Im E, Dolled-Filhart M, Garon EB: Pembrolizumab versus docetaxel for previously treated, PD-L1-positive, advanced non-small-cell lung cancer (KEYNOTE-010): a randomised controlled trial. Lancet 2016;387:1540-1550.

54 Rizvi NA, Hellmann MD, Snyder A, Kvistborg P, Makarov V, Havel JJ, Lee W, Yuan J, Wong P, Ho TS, Miller ML, Rekhtman N, Moreira AL, Ibrahim F, Bruggeman C, Gasmi B, Zappasodi R, Maeda Y, Sander C, Garon EB, Merghoub T, Wolchok JD, Schumacher TN, Chan TA: Cancer immunology. Mutational landscape determines sensitivity to PD-1 blockade in non-small cell lung cancer. Science 2015;348: 124-128

55 Ascierto PA, Capone M, Urba WJ, Bifulco CB, Botti G, Lugli A, Marincola FM, Ciliberto G, Galon J, Fox BA: The additional facet of immunoscore: immunoprofiling as a possible predictive tool for cancer treatment. J Transl Med 2013;11:54.

56 Herbst RS, Soria JC, Kowanetz M, Fine GD, Hamid O, Gordon MS, Sosman JA, McDermott DF, Powderly JD, Gettinger SN, Kohrt HE, Horn L, Lawrence DP, Rost S, Leabman M, Xiao Y, Mokatrin A, Koeppen H, Hegde PS, Mellman I, Chen DS, Hodi FS: Predictive correlates of response to the anti-PD-L1 antibody MPDL3280A in cancer patients. Nature 2014;515:563567.

57 Messina JL, Fenstermacher DA, Eschrich S, Qu X, Berglund AE, Lloyd MC, Schell MJ, Sondak VK, Weber JS, Mule JJ: 12-Chemokine gene signature identifies lymph node-like structures in melanoma: potential for patient selection for immunotherapy? Sci Rep 2012;2: 765. 